\title{
Mediastinal/hiler granülomatöz lenfadenit etyolojisi
}

\author{
Müge ERBAY ${ }^{1}$ \\ Savaş ÖZSU ${ }^{1}$ \\ Emine Sevil AYAYDIN \\ MÜRTEZAOĞLU ${ }^{1}$ \\ Atila TÜRKYILMAZ \\ Neslihan ÖZÇELIK ${ }^{2}$ \\ Yılmaz BÜLBÜL ${ }^{1}$ \\ Şafak ERSÖZ ${ }^{3}$
}

\footnotetext{
1 Karadeniz Teknik Üniversitesi Tıp Fakültesi, Göğüs Hastalıkları Anabilim Dalı, Trabzon, Türkiye

${ }^{1}$ Department of Chest Diseases, Faculty of Medicine, Karadeniz Teknik University, Trabzon, Turkey

${ }^{2}$ Kaçkar Devlet Hastanesi, Göğüs Hastalıkları Kliniği, Rize, Türkiye

${ }^{2}$ Clinic of Chest Diseases, Kackar State Hospital, Rize, Turkey

${ }^{3}$ Karadeniz Teknik Üniversitesi Tıp Fakültesi, Patoloji Anabilim Dalı, Trabzon, Türkiye

${ }^{3}$ Department of Pathology, Faculty of Medicine, Karadeniz Teknik University, Trabzon, Turkey
}

\section{ÖZET}

\section{Mediastinal/hiler granülomatöz lenfadenit etyolojisi}

Giriș: Granülom oluşumu çeşitli infeksiyöz ve infeksiyöz olmayan ajanlar tarafından başlatılan kronik bir inflamatuvar yanıtı temsil etmektedir. Özellikle infeksiyöz dışı nedenlere bağıı granülomatöz nedenler klinisyenleri oldukça zorlamaktadır.

Materyal ve Metod: Bu çalışmada Eylül 2014 ile Aralık 2016 arasında EBUS ya da mediastinoskopiyle mediastinal/hiler lenfadenopatilerin (LAP) histopatolojik değerlendirmesinde granülomatöz lenfadenit tanısı alan hastaların dă̆ılımı araştırılmıştır. Uyumlu histolojik, radyolojik ve klinik bulgularla birlikte kültür negatifliği olduğunda 'güvenli' sarkoidoz olarak tanımlandı. Dokuda mikroorganizma görülmesi, kültür pozitifliği, tutarlı klinikopatolojik durumda pozitif seroloji veya pozitif antijen saptanması durumunda 'güvenli' infeksiyöz olarak kaydedildi.

Bulgular: Toplam 110 hastada granülomatöz LAP saptandı. Hastaların \%70.9'u kadın cinsiyetindeydi ve ortalama yaş 53 (range 44-61)'tü. Yetmiş dokuz (\%71.8) hastada sarkoidoz, 7 (\%6.4) hastada tümör ilişkili granülom, 4 (\%3.6) hastada tüberküloz, 4 (\%3.6) hastada silikozis, 2 hastada (\% 1.8) ilaç ilişkili granülom, 1 (\%0.9) hastada hipersensitivite pnömonisi, 1 (\%0.9) hastada Chron hastalığı, 12 (\% 10.9) hastada nedeni bilinmeyen granülom saptandı. Tüberküloz tanısı 3 hastada kültür pozitifliğiyle konuldu.

Sonuç: Bu çalışmada granülomatöz lenfadenitin en sık sebebinin sarkoidoz olduğu saptandı. Beklenenin aksine tüberküloz tanısı alan hasta sayısı oldukça düşüktü.

Anahtar kelimeler: Granülom; lenfadenit; sarkoidoz

\section{SUMMARY}

Causes of mediastinal/hilar granulomatous lymphadenitis

Introduction: Granulomatous lung disease (GLD) is caused by a wide range of conditions and it is challenge for pulmonologist. A detailed history of exposures is fundamental in GDL and has been found pivotal to reach a precise diagnosis.

\section{Yazışma Adresi (Address for Correspondence)}

Dr. Müge ERBAY

Karadeniz Teknik Üniversitesi Tıp Fakültesi, Göğüs Hastalıkları Anabilim Dalı, TRABZON - TÜRKIYE

e-mail: drmugerbay@gmail.com 
Materials and Methods: Between September 2014 and December 2016, the distribution of patients diagnosed with granulomatous lymphadenitis in the mediastinal/hilar lymph nodes by endobronchial ultrasound (EBUS) or mediastinoscopy was analyzed. To be listed as 'confident', a diagnosis of sarcoidosis required compatible histological, radiological and clinical findings in conjunction with negative cultures. Infectious entities listed as 'confident' had either microorganisms in tissue section, positive culture, positive serology or positive antigen detection in a consistent clinical pathological setting.

Results: Granulomatous lymphadenitis was detected in 110 patients. The included 110 cases consisted of $70.9 \%$ women and median age of 53 (range 44-61) years. The final diagnosis of the patients was accepted to be sarcoidosis in 79 (71.8\%), sarcoid like granulomas in $7(6.4 \%)$, tuberculosis in $4(3.6 \%)$, silicosis in $4(3.6 \%)$, drug-associated granuloma in $2(1.8 \%)$, hypersensitivity pneumonitis in $1(0.9 \%)$, Chron disease in $1(0.9 \%)$, unspecified in $12(10.9 \%)$. Three patients were classified as tuberculosis based on culture.

Conclusion: In this study, we found that the most common cause of granulomatous lymphadenitis was sarcoidosis. Contrary to expectations, the number of patients diagnosed with tuberculosis was very low.

Key words: Granuloma; lymphadenitis; sarcoidosis

\section{GíRiş}

Mediasten, çok sayıda lenf nodlarıyla zengin lenfatik ağa sahiptir. Mediastinal/hiler lenf nodu büyümesinin etyolojisi lenfoma, metastatik karsinom, sarkoidoz ve tüberküloz (TB) gibi geniş bir hastalık grubunu içermektedir. Ayrıca mononükleer inflamatuvar hücre agregasyonu veya çoğunlukla çok nükleuslu dev hücreler içeren, genellikle lenfositlerden oluşan bir sinir ile çevrelenmiş, epitelyum hücrelerinin bir araya gelmesinden oluşan modifiye makrofaj kümelenmesi olan "granülom" oluşumu; çeşitli infeksiyöz veya infeksiyöz olmayan ajanlar tarafından başlatılan kronik bir inflamatuvar yanıtı temsil etmektedir. Sonuç olarak granülomatöz mediastinal/hiler lenfadenit sıklıkla karşımıza çıkmakta ve özellikle infeksiyöz dışı nedenlerin ayrımında klinisyenler oldukça zorlanmaktadır.

Amerika'da yapılan bir çalışmada pulmoner granülomatöz inflamasyon nedenleri; 226 hastanın $\% 54.7$ 'sinde infeksiyöz, \%26.8'inde non-infeksiyöz ve kalan \%18.4'ünde ise idiyopatik olarak sınıflandırılmıştır (1). Akciğer rezeksiyonu sonucu granülom saptanan 131 hastanın incelendiği bir seride ise hastaların $\% 49^{\prime}$ unda infeksiyöz nedenler, \%11'inde noninfeksiyöz nedenler bulunmuş ve \%40'ında ise herhangi bir neden bulunamamıştır (2).

Ayırıcı tanı bizler için, etyolojiye göre tedavide farklılıklar (immünsüpresif tedavi, antibiyoterapi) olması nedeniyle büyük önem taşımaktadır. Etyolojinin belirlenmesinde klinik, mikrobiyolojik ve radyolojik verilerin patoloji ve öyküyle birlikte değerlendirilmesi yardımcı olabilir. Yine de nihai tanıya ulaşılamayan durumlar söz konusu olmaktadır. Çalışmamızda granülomatöz lenfadenit nedenlerinin dağılımı incelenmiş ve klinisyenlere yol gösterici olması amaçlanmıştır.

\section{MATERYAL ve METOD}

$\mathrm{Bu}$ çalışma 3. basamak bir üniversite hastanesinde Eylül 2014 ile Aralık 2016 tarihleri arasında retrospektif olarak yürütüldü. Çalışmaya hastanemize başvuran ve kısa çapı $1 \mathrm{~cm}$ 'den büyük mediastinal/hiler lenfadenopati nedeniyle endobronşiyal ultrasonografi (EBUS)/ mediastinoskopi/torakoskopi gibi bir invaziv işlem uygulanan ve granülomatöz lenfadenit tanısı alan olgular alındı.

Biyopsi materyallerinden asite rezistan basil (ARB) ve Mycobacterium tuberculosis kültürü bakısı yapıldı. Granülomatöz inflamasyon histopatolojik olarak nekrotizan veya nonnekrotizan olarak sınıflandırıldı. Hastaların öyküsü (kanser öyküsü, ilaç kullanımı), laboratuvar parametreleri (anjiotensin konverting enzim (ACE), tüberkülin deri testi (TDT) ve patoloji sonuçları kaydedildi. Serum ACE düzeyi normal değeri 0-52 U/L'ydi.

Uyumlu histolojik, radyolojik ve klinik bulgularla birlikte kültür negatifliği olduğunda sarkoidoz olarak tanımlandı (3). Dokuda mikroorganizma görülmesi, tutarlı klinikopatolojik bulguyla pozitif seroloji veya pozitif antijen saptanması ve kültür pozitifliği olması durumunda infeksiyöz olarak tanımlandı. Uygun mesleki anamnez ve maruziyet öyküsü olan, uyumlu radyolojik değişiklik ve bu radyolojik görüntüye yol açacak infeksiyöz, kanser, kollajenözler başta olmak üzere inflamatuvar nedenlerin dışlandığı hastalar pnömokonyoz olarak kabul edildi. Bu kriterlerle uyumlu olmayan hastalar, eşlik eden bir malignite olmaması, granülomatöz hastalığa ve lenfadenopatiye neden olduğu bilinen ilaç kullanımı olmaması halinde idiyopatik olarak kabul edildi. Kolonoskopi bulgularıyla Chron hastalığı tanısı alan, klinik ve laboratuvar bulgularla sarkoidoz ve diğer etyolojilerin dışlandığı olgular 
Chron ilişkili granülomatöz lenfadenit olarak tanımlandı.

\section{İstatistiksel Analiz}

Veriler bilgisayar ortamında SPSS 23 yazılım programı kullanılarak değerlendirildi. Verilerin dağılımı için Kolmogorov-Smirnov analizi yapıldı. İstatiksel yöntemde parametrik değişkenler için ki-kare ve student-t testi, nonparametrik değişkenler için Mann-Whitney U ve Kruskal Wallis analizi kullanıldı. İstatiksel olarak anlamlı değer $p<0.05$ olarak kabul edildi.

\section{BULGULAR}

Çalışmaya toplam 110 hasta alındı ve hastaların $\% 70.9^{\prime}$ u kadındı. Yaş ortalaması 53 (range 44-61)'tü. Sarkoidoz hastalarının \%72.2'si, tüberküloz hastalarının \%75'i ve diğerlerinin \%66.7'si kadındı $(p=8)$. Sarkoidozlu hastalarda ortalama yaş 54 (range 19-87), tüberkülozda 50 (range 46-56) ve diğer durumlarda 51 (range 33-86)'di $(\mathrm{p}=0.3)$.

Hastaların \%76.4'üne tanı EBUS ile, \%21.8'ine mediastinoskopiyle, \%0.9'una periferik lenf nodu biyopsisi ve $\% 0.9^{\prime}$ una torakoskopiyle tanı konuldu. Sarkoidoz tanısı alan hastaların \%82.3'ü EBUS ile, \%17.7'si ise mediastinoskopiyle tanı aldı.

Mediastinal/hiler LAP örneklemesinde ilk tanısal işlem olarak 5 hastaya mediastinoskopi, 1 hastaya torakoskopi yapıldı. illk tanısal işlem olarak EBUS TBIA yerine mediastinoskopi, torakoskopi yapılmasının nedenlerine bakıldığında; EBUS TBiA'ya uygun olmamalarına ya da ilk olarak cerrahi polikliniğine başvurmalarına bağlı olduğu görüldü.

EBUS TBiA ile granülomatöz lenfadenit olduğu tespit edilen 4 hastaya mediastinoskopi yapıldı ve sonuç benzer bulundu. EBUS TBIA ile spesifik bulgu elde edilemeyen ve mediastinoskopi yapılan 10 hastada granülomatöz lenfadenit saptandı.

Hastaların \%85.5'inde non-infeksiyöz, \%3.6'sında tüberküloz ve \%10.9'unda idiyopatik nedenler söz konusuydu. Sarkoidoz non-infeksiyöz nedenler içerisinde en sık görülendi (\%71.8) (Tablo 1). Sarkoidozlu hastaların \%57.1'i evre I, \%39.7'si evre II, \%1.6'sı evre III ve \%1.6'sı evre IV'tü.

Tümör ilişkili granülom tanısı alan 7 hastanın; 2'sinde endometriyum kanseri, 2'sinde meme kanseri, 1'inde kolon kanseri, 1 'inde lenfoma ve 1 'inde sarkom öyküsü mevcuttu. Bu hastaların maligniteleri lenf nodu örneklenmesiyle eş zamanlı olmayıp öncesinde kanser tanısı almış ve tedavi uygulanmıştı. Malignite öyküsü
Tablo 1. Mediastinal/hiler granülomatöz lenfadenit nedenleri

\begin{tabular}{|lc|} 
& Hasta sayısı (\%) \\
\hline Sarkoidoz & $79(71.8)$ \\
Tümör ilişkili granülom & $7(6.4)$ \\
Tüberküloz & $4(3.6)$ \\
Silikozis & $4(3.6)$ \\
İlaç ilişkili (Anti-TNF) & $2(1.8)$ \\
Chron hastalığı & $1(0.9)$ \\
Hipersensitivite pnömonisi & $1(0.9)$ \\
İdiyopatik & $12(10.9)$ \\
\hline
\end{tabular}

olan hastalarımızın lenf bezi örneklerinde tümör metastazı saptanmadı.

Tüberküloz tanısı; 3 hastada kültür pozitifliğiyle, 1 hastada klinik-radyolojik bulgular ve tüberküloz tedavisine yanıt vermesiyle konuldu. Tüberküloz tanısı konan 4 hastada TB PCR negatif bulundu. Başlangıçta TB tedavisi verilen bir hastaya daha sonra sarkoidoz tanısı konuldu.

Hastaların histopatolojik değerlendirmesinde $\% 65.5$ 'inde nonnekrotizan granülom, \%10'unda nekrotizan granülom saptandı ve $\% 24.5$ 'inde nekroz ayrımı yapılamadı. Sarkoidoz tanısı konulan hastaların 2'sinde biyopside nekroz mevcuttu.

Serum ACE düzeyi 90 hastada bakıldı ve ortalama 62 U/L olarak bulundu. ACE düzeyi sarkoidozda 65 ( $\mathrm{min}$ 15-max 198) U/L, tüberkülozda 51 (min 33-max 102) U/L ve diğer durumlarda 50 (min 19-max 112) U/L olarak bulundu. Serum ACE seviyesi sarkoidozda diğer nedenlere bağlı durumlardan daha yüksekti $(p=0.31)$. Sarkoidozlu hastaların \%71.2'sinde, diğer durumların \%43.5'inde serum ACE düzeyi yüksek bulundu $(p=0.33)$.

Ortalama tüberkülin deri testi (TDT) değeri $10 \mathrm{~mm}$ (min 0-max $35 \mathrm{~mm}$ ) bulundu. Ortalama TDT sarkoidozda $3 \mathrm{~mm}$ iken, tüberkülozda $21 \mathrm{~mm}$, diğer durumlarda $14 \mathrm{~mm}$ idi.

\section{TARTIŞMA}

Granülom, epiteloid aktive makrofajların kümelenmesi ile karakterizedir ve geniş bir yelpazede (malign, nonmalign) çeşitli durumlarda görülebilir. Çalışmamızda granülomatöz lenfadenit olgularımızın çoğunluğunu sarkoidoz (\%72) oluşturmaktadır. Diğer nedenler arasında \%3.6'sında tüberküloz yer alırken, $\% 10.9^{\prime}$ unda ise herhangi bir neden bulunamamışır. 
Altta yatan hastalığa bağıı olarak bölgesel lenf nodlarında sarkoidoza benzeyen epiteloid granülomlar görülebilir ve bu sarkoid benzeri reaksiyon olarak tanımlanır (4). Birçok nedene bağlı görülebilir, bunlardan bazıları; kanser (uterus, meme, akciğer, mide), fungal ve mikobakteriyal infeksiyon, kemoterapi, hipersensitivite pnömonisi, berilyoz, primer biliyer siroz, Crohn hastalığıdır (5). Karsinomlarda \%4.4, akciğer kanserinde \%2.2-3.4, Hodgkin lenfomaların ise \%14'ünde sarkoid reaksiyon gözlenmektedir (6). Bir çalışmada endobronşiyal ultrason eşliğinde transbronşiyal iğne aspirasyonu (EBUS-TBiA) yapılan 1275 hastanın 154 (\%12.1)'ünde granülomatöz inflamasyon izlenmiştir. Bu hastaların 12 (\%7.8)'sinde histolojik veya sitolojik olarak eş zamanlı malignite tespit edilmiş olup hiçbirinde fungal veya mikobakteriyal infeksiyonu düşündüren öykü, seroloji, doku veya kültür pozitifliği veya sarkoidoz öyküsü bulunmamaktadır (7).

Çalışmamızda granülomatöz lenfadenit saptanan 10 hastada malignite öyküsü ve bunların 7'sinde maligniteyle ilişkili granülom mevcuttu. Granülomatöz mediastinal lenfadenopati, çeşitli malignite öyküsü olan hastalarda ilk tanıdan sonra 8 yıla kadar, hastaların \%5 veya daha azında kanser nüksü olarak ortaya çıkabilmektedir (8). Başka bir çalışmada, küçük hücreli dışı akciğer kanseri tanısıyla rezeksiyon yapılan 1027 hastanın 51'inde, lenf düğümlerinde (mediastinal/bronşiyal) veya akciğer parankiminde nekrotizan granülomatöz inflamasyon saptanmıştır (9).

Nazarullah ve arkadaşlarının pulmoner granülomatöz inflamasyon nedenleri ve insidansını araştırdıkları çalışmalarında granülomatöz akciğer hastalığı olan 190 hastanın \%54.7'si (104\190) infeksiyöz, \%26.8'i (51\190) infeksiyöz olmayan ve \%18.4'ü (35\190) nedeni bilinmeyen olarak saptanmışır. İnfeksiyöz nedene bağlı olanların 52'sinde mikobakteri mevcutken infeksiyöz olmayanların en sık nedeni sarkoidoz (39\51) olarak bulunmuştur (1). Pulmoner granülom nedenlerinin araştırıldığı 500 vaka içeren retrospektif bir çalışmada, vakaların \%58'inde (290/500) spesifik bir neden olup en yaygın olarak da sarkoidoz (136, $\% 27)$ ve mikobakteri veya fungal infeksiyonlar (125, \%25) saptanmıştır (10). Gürünkaya ve arkadaşlarının çalışmasında granülomatöz lenfadenit saptanan 134 hastada en sık neden sarkoidoz (82, \%61.2), ikinci sık neden TB (24, \%17.9) olurken, 20 (\%14.9) hastada belirli bir tanı elde edilememiştir (11). Yine ülkemizde yapılan bir çalışmada histopatolojik olarak granülom saptanan 884 hastanın 771'inde (\%84.3) sarkoidoz tanısı konulmuştur (12). Bizim çalışmamızda ise sarkoidoz tanısı \%72 olarak saptanmıştır.

Çalışmamızda tüberküloz saptanan hasta sayısı beklenenin aksine oldukça düşük (\%3.6) bulunmuştur. Dört hastanın 3'üne tüberküloz kültür pozitifliğiyle, diğer hastada ise klinik ve radyolojik bulgulara göre TB tanısı konulmuştur. Ülkemizden yapılan bir çalışmada EBUS ile TB tanısı konan 30 hastanın \%16.7'sinde yayma pozitif bulunmuşken \%20'sinde kültür pozitifliği saptanmıştır. Aynı çalışmada hastaların \%55'inde TB PCR pozitif bulunmuştur (13).

TB tanısında, kültür altın standart olmakla birlikte sınırlı olduğunu bilmekteyiz (14). Lenf nodunda TB ARB ve kültür duyarlılığı düşük olup olguların \%39 ila 80'inde kültürde mikobakteri görülebilir (15). Çalışmamızda kültür pozitifliğinin düşük olması önceki çalışmalarla benzer olarak; analizlere gönderilen örneklerde basilin eşit olmayan dağııımına, ekstrapulmoner TB'deki düşük basil yoğunluğuna bağlı olabilir.

Alternatif tanısal yöntem olarak birçok çalışma, plevral efüzyon ve lenfadeniti içeren ekstrapulmoner tüberküloz tanısında PCR tekniğini önermektedir $(16,17)$. Tüberküloz lenfadenitte nükleik asit amplifikasyon testi de kullanılmaktadır. Fakat bununla ilgili çalışmalara bakıldığında hem yanlış pozitif hem de yanlış negatif sonuçlar mümkün olduğu için, geleneksel yöntemlerle birlikte ve klinik şüphe durumunda uygulanabilirliği vurgulanmaktadır (18).

Bunun dışında MPT64 antijen testinin ekstrapulmoner tüberküloz tanısında kullanımı ile ilgili çalışmalar bulunmaktadır $(19,20)$. MPT64, non-tüberküloz mikobakterilerde saptanmayan, Mycobacterium tuberculosis kompleks türleri tarafından salgılanan bir proteindir. Jorstad ve arkadaşları tarafından MPT64 testinin, TB vakalarında \%83'lük duyarlılıkla diğer tanı testlerine (ARB, kültür, Xpert testi) göre daha iyi olduğu saptanmıştır (21).

Çalışmamızın bazı kısıtıııkları bulunmaktadır. Birincisi mikrobiyolojik değerlendirmenin tüm hastalarda yapılmamış olmasıdır. Bu durum TB dışı infeksiyöz nedenlerin atlanmasına neden olabilir. Örneğin tularemi ve brusella serolojisi tüm hastalarda çalışılmamıştır. Ülkemizde yapılan bir çalışmada TB lenfadenitli hastaların \%6.7'sinde tularemi serolojisinin pozitif olduğu gösterilmiştir (22). Çalışmamızın bir başka limitasyonu ise retrospektif ve tek merkezli bir çalışma olmasıdır. 


\section{KAYNAKLAR}

1. Nazarullah A, Nilson R, Maselli DJ, Jagirdar J. Incidence and aetiologies of pulmonary granulomatous inflammation: A decade of experience. Respirology 2015;20:115-21.

2. Mukhopadhyay S, Wilcox BE, Myers IL, Bryant SC, Buckwalter SP, Wengenack NL, et al. Pulmonary necrotizing granulomas of unknown cause: clinical and pathologic analysis of 131 patients with completely resected nodules. Chest 2013;144:813-24.

3. Govender P, Berman JS. The diagnosis of sarcoidosis. Clin Chest Med 2015;36:585-602.

4. Brincker H. Sarcoid reactions in malignant tumours. Cancer Treat Rev 1986;13:147-56.

5. Shigeyuki Asano. Granulomatous lymphadenitis. J Clin Exp Hematopatho 2012;52:1-16.

6. Brunner A, Kantner J, Tzankov A. Granulomatous reactions cause symptoms or clinically imitate treatment resistance in small lymphocytic lymphoma/chronic lymphocytic leukaemia more frequently than in other non-Hodgkin lymphomas. J Clin Pathol 2005;58:815-9.

7. DePew ZS, Gonsalves WI, Roden AC, Bungum AO, Mullon JI, Maldonado F. Granulomatous inflammation detected by endobronchial ultrasound-guided transbronchial needle aspiration in patients with a concurrent diagnosis of cancer a clinical conundrum. J Bronchol Intervent Pulmonol 2012;19:176-81.

8. Kennedy M, Jimenez C, Mhatre A, Morice RC, Eapen GA. Clinical implications of granulomatous inflammation detected by endobronchial ultrasound transbronchial needle aspiration in patients with suspected cancer recurrence in the mediastinum. I Cardiothorac Surg 2008;3:8-12.

9. Yakar F, Yakar A, Büyükpınarbaşılı N, Erelel M. Does every necrotizing granulomatous inflammation identified by NSCLC resection material require treatment? Med Sci Monit 2016;22:1218-22.

10. Mukhopadhyay S, Farver CF, Vaszar LT, Dempsey OJ, Popper HH, Mani H, et al. Causes of pulmonary granulomas: a retrospective study of 500 cases from seven countries. J Clin Pathol 2012;65:51-7.

11. Gürün Kaya A, Çiledag A, Çiftçi F, Sen E, Ceyhan K, Kaya $A$, et al. The underlying causes of granulomatous lymphadenitis detected by EBUS-TBNA. European Respiratory Journal 2015;46:788.

12. Musellim B, Okumus G, Uzaslan E, Akgün M, Cetinkaya E, Turan $O$, et al. Turkish interstitial lung diseases group. Epidemiology and distribution of interstitial lung diseases in Turkey. Clin Respir J 2014;8:55-62.
13. Senturk A, Arguder E, Hezer H, Babaoglu E, Kilic $H$, Karalezli $A$, et al. Rapid diagnosis of mediastinal tuberculosis with polymerase chain reaction evaluation of aspirated material taken by endobronchial ultrasoundguided transbronchial needle aspiration. I Investig Med 2014;62:885-9.

14. Denkinger CM, Schumacher SG, Boehme CC, Dendukuri $N$, Pai M, Steingart KR. Xpert MTB/RIF assay for the diagnosis of extrapulmonary tuberculosis: a systematic review and meta-analysis. Eur Respir J 2014;44:435 \pm 46 .

15. Chakravorty S, Sen MK, Tyagi JS. Diagnosis of extrapulmonary tuberculosis by smear, culture, and PCR using universal sample processing technology. J Clin Microbiol 2005; 43:4357 \pm 62 .

16. Goel MM, Ranjan V, Dhole TN, Srivastava AN, Mehrotra $A$, Khushwaha MR, et al. Polymerase chain reaction versus conventional diagnosis in aspirates of tuberculous lymph nodes. Acta Cytol 2001;45:333-40.

17. Baek CH, Kim SI, Ko YH, Chu KC. Polymerase chain reaction detection of Mycobacterium from FNA for diagnosis of cervical tuberculosis. Laryngoscope 2000; 110:30-4.

18. Daley P, Thomas S, Pai M. Nucleic acid amplification tests for the diagnosis of tuberculous lymphadenitis: a systematic review. Int J Tuberc Lung Dis 2007; 11:1166 76 .

19. Mustafa T, Wiker HG, Mfinanga SG, Morkve O, Sviland L. Immunohistochemistry using a Mycobacterium tuberculosis complex specific antibody for improved diagnosis of tuberculous lymphadenitis. Mod Pathol 2006; 19:1606 \pm 14 .

20. Purohit MR, Mustafa T, Wiker HG, Morkve O, Sviland L. Immunohistochemical diagnosis of abdominal and lymph node tuberculosis by detecting Mycobacterium tuberculosis complex specific antigen MPT64. Diagn Pathol 2007;2:36.

21. Jørstad MD, Marijani M, Dyrhol-Riise AM, Sviland L, Mustafa T. MPT64 antigen detection test improves routine diagnosis of extrapulmonary tuberculosis in a lowresource setting: A study from the tertiary care hospital in Zanzibar. PLoS One 2018;13:e0196723.

22. Karabay O, Kilic S, Gurcan S, Pelitli T, Karadenizli A, Bozkurt $H$, et al. Cervical lymphadenitis: tuberculosis or tularaemia? Clin Microbiol Infect 2013;19:113-7. 